\title{
ALGUNS ASPECTOS DA PROBLEMÁTICA MÉDICO-SOCIAL DO COMPLEXO DE INFERIORIDADE
}

\author{
Napoleão L. Teixeira \\ Professor da Universidade do Paraná: \\ Catedrático de Medicina Legal (Facul- \\ dade de Direito) e de Clínica Psiquiátrica \\ (Faculdade de Medicina)
}

\section{I - TENDENCIA DE DOMfNIO E MANDO}

Comecemos com uma afirmação, sobremodo conhecida dos psicólogos: todo complexo de inferioridade é, em derradeira análise, fruto do insucesso da tendência dominadora que existe em todos nós.

Essa tendência dominadora não é apanágio da criatura humana. Vêmo-la também nos animais. Observe-se como se batem pela posse da fêmea, ou pelo comando do rebanho; como lutam por um pouco de alimento e como o vencedor foge com sua prêsa, com mêdo que a arrebatem.

Veja-se, agora, através da História, como a tendência dominadora leva o homem a tudo querer conquistar: ao mundo físico, pela ciência e pela indústria; ao mundo social, pela habilidade, ou pela fôrça. A História Política seria a das tentativas de despotismo e do imperialismo, destinadas a satisfazer à necessidade de supremacia que existe em todo o homem e em tôda nação. A História das Religiões mostraria, em lugar de destaque, a luta pela propagação e implantação das crenças, em homens e povos.

Haveria, pois, em cada um de nós, uma tendência de domínio e mando, que seria, em derradeira análise, o primum movens de tôdas as nossas atividades, na vida. 
Como nasceria ela? De onde proviria? Qual sua gênese? Qual sua dinâmica?

E o que procuraremos explicar.

\section{II - "SENTIMENTO" DE INFERIORIDADE E "COMPLEXO" DE INFERIORIDADE}

Para tanto, remontemos à criança. Ensina Alfred Adler - discípulo dissidente de Freud, fundador da Escola Psicológica Individual - haver, em tôda criatura humana, ao nascer, sob forma rudimentar, penosa impressão de desvalor, inferioridade, desamparo (Minderwertigkeitsgefühl), que a levaria a uma angústia mortal, não fôra o impulso de agressão e domínio (agressionstrieb) - comparável à "vontade de poder" (Wille zur Macht) de Schopenhauer e Nietszche - e também o sentimento de comunidade (Gemeinschaftsgefühl) que a impeliria a unir-se aos demais do grupo social em que vive.

A medida que evolui e cresce, sentindo-se inferior, lutando contra essa inferioridade através da sua tendência dominadora, antepõe-se, à criança, desde os primeiros dias da vida, obstáculos que lhe contrariam a satisfação dos desejos - e é então que se torna consciente da sua debilidade, por sair sempre vencida na luta contra os adultos. Dêsse insucesso, resulta seu sentimento de inferioridade que é, portanto - frisemos êste ponto - normal em tôda a criança. Nada tendo de prejudicial, ajuda-a até; estimula, nela, o desejo de "ser grande", de "fazer como o papá ou como a mamãe", de imitar os seus maiores.

Graças ao protesto viril, é que procurará superar o sofrimento acarretado pela percepção de sua inferioridade. O sentimento de inferioridade individual (normal, repitamos), transformar-se-á na "mais prodigiosa das molas que impulsionam a criança a educar-se a si mesma" - ensina o psicólogo alemão Weisberg. E o referido sentimento de inferioridade ir-se-á desvanecendo, a pouco e pouco, à proporção que a personalidade se afirme.

Todo indivíduo tem de solucionar três problemas, na vida: o problema social (afirmar-se e ter prestígio no meio em que vive); o problema profissional (vencer na profissão); o 
problema sexual (realizar-se, normalmente, no sexo). Não o consiga, no todo ou em parte - e será um frustrado.

Nem sempre, infelizmente, a pessoa consegue "liquidar", satisfatòriamente, seu sentimento de inferioridade. Causas diversas podem concorrer para a fixação do mesmo, que passará a ser, daí por diante, como um espinho cravado na carne moral (digamos assim), uma cicatriz dolorosa, ponto sensível para a vida tôda, fonte de sofrimento psicológico e das mais variadas reações de defesa.

Passa, então, a ser um complexo de inferioridade. Se o sentimento de inferioridade é, de início, normal em todos nós, já o complexo de inferioridade deve ser compreendido como uma condição patológica, encontradiço em algumas pessoas. Em algumas, não em tôdas - e é nisto que o complexo se distingue do sentimento de inferioridade, como tivemos oportunidade de mostrar.

\section{III - CAUSAS}

Se quisermos estudar as causas do complexo de inferioridade, deveremos classificá-las em três grupos:

A) - INFLUÊNCIA DESFAVORÁVEL DO MEIO

B) - INFERIORIDADE REAL, ORGÂNICA OU PSICOLÓGICA

C) - ANOMALIA EXTRAVAgANTE OU RIDICULA

Passemos cada uma delas, em rápida revista:

A) - INFLUÊNCIA DESFAVORÁVEL DO MEIO - Seja do meio familiar e escolar, seja do meio social.

1) - INFLUENCIA DO MEIO FAMILIAR E ESCOLAR:

Recordem-se, aqui, pais vaidosos que, envergonhados de não terem um filho genial, o comparam, amiúde, a um parente mais bem dotado, ou a um amigo brilhante, recriminando-o por não se lhes igualar; ou então, irmãos maiores que tratam como a um bebêzinho o irmão menor, ridicularizando-o, sobretudo (inveja subconsciente) se êste irmão é mais inteligente que êles; ou ainda, caso do professor que achincalha o aluno diante da classe, quando êste tem convic- 
ção de haver feito bom trabalho; caso também, corolário do anterior, do estudante humilhado nos chamados "quadros de honra" escolares, através dos quais se exerce, muitas vêzes, a vingança de determinada fauna de professôres, recalcados, contra pobres estudantes, indefesos em face do sadismo daqueles; caso, por igual, de camaradas mais fortes que se prevalecem e tiranizam os mais débeis. "Em geral" - ensina Claparède - "em geral, exigir de uma criança mais do que é capaz de dar, é predispô-la ao complexo de inferioridade, porque se a condena a jamais obter um resultado satisfatório, a nunca colhêr o fruto do seu esfôrço; não sòmente deixa de satisfazer aos outros, porém - o que é mais grave - tampouco fica contente consigo própria, fixando-se no seu espírito, cada vez mais profundamente, a idéia de se achar abaixo do nível normal".

Paradoxal que pareça, mimos excessivos, êxitos ruidosos de filhos, irmãozinhos, netos ou sobrinhos "muito inteligentes!", nos primeiros anos de vida, podem levar a criança ao complexo de inferioridade; explica-se: se a grande confiança que tem em si mesma (fruto de experiências demasiado fáceis no meio em que foi criada), é desmentida por novas experiências num meio estranho, poderá decepcionar-se, desiludir-se. Esta é a razão por que as crianças, excessivamente mimadas por irmãos, tios ou avós podem vir pagar pesado tributo ao complexo de inferioridade: tombadas do lar, paraíso em que imperavam, na escola - inferno em que suas vontades de ditadorazinhas não são acatadas - se incapazes de se ajustarem ao novo meio, caem nas garras do complexo de inferioridade.

\section{2) - INFLUÊNCIA DO MEIO SOCIAL}

A condição humilde pode ser causa de que, na criança, se estruture o complexo de inferioridade. Os filhos das classes menos favorecidas pela fortuna, amiúde menos bem alimentados, menos alvo de carinho e de atenções, desde cedo encarregados de trabalhos de adultos sem a posição e os privilégios dêstes, comparando suas condições de vida com as das crianças remediadas ou ricas, sofrem, muitas vêzes, vivamente, com a inferioridade da sua condição - e, disso, poderá redundar o complexo de inferioridade. Não só a condição hu- 
milde, a pobreza dos primeiros anos de vida; o desamparo também, e não apenas o desamparo verdadeiro, encontradiço nos materialmente abandonados, que constituem a legião dos pequenos miseráveis, que poderão vir a ser os criminosos de amanhã, mas também essoutro abandono - infinitivamente pior, mais grave, mais sério e mais triste - que é o abandono afetivo, tão comum hoje nas classes ricas, em que pais irresponsáveis, às voltas com rodas de jôgo, com atividades sociais e "atividades" outras as mais díspares, abandonam, literalmente, os filhos menores, quando não os entregam a cuidados mercenários. Serão, êstes, a nosso ver, menores bem mais abandonados que os primeiros - e vêmo-los, em bando, a vaguear pelos clubes aristocráticos, aprendendo nos seus gramados o que não serve; vendo, nas telas dos cinemas clubescos, lições de filmes altamente deletérios para suas mentes ainda na formação; assistindo, no "cinema" familiar (e será isso família?!...), a outras lições que ficarão para sempre, gravadas a fogo, no seu espírito.

Vimos, até aqui, a influência do meio familiar e escolar na gênese e na estruturação do complexo de inferioridade. Vejamos, agora, a segunda causa, ou seja

B) - INFLUENNCIA DE UMA INFERIORIDADE REAL, ORGÂNICA OU PSICOLÓGICA

O complexo de inferioridade pode ter suas raízes num sentimento de inferioridade real, orgânica ou psicológica. Quando o menor, por fôrça de enfermidade, debilidade corporal, defeito físico, diferença racial, pigmentação da pele, atraso intelectual, etc., sofre remoques e humilhações dos companheiros (sabe-se que a infância não conhece a piedade), ou ouve freqüentes queixas a seu respeito por parte dos famaliares - sofre, intensamente, com isso. Alinhem-se, aqui: os coxos; os corcundas; os paralíticos; os deficitários da visão ou da audição; os displásicos e aleijados em geral; todos aquêles que são alvo de preconceitos de raça, côr ou religião, nos países em que êstes existem (e, felizmente, nosso Brasil não é um dêles). A vivência da "certeza" de sua inferioridade face aos demais e o sofrimento da mesma decorrente, poderá levá-lo ao complexo de inferioridade.

Vejamos, finalmente, a terceira causa, que é 


\section{C) - ANOMALIA EXTRAVAGANTE OU RIDICULA}

Qualquer caráter insólito ou estranho em uma criança, pode atrair, sôbre a mesma, o ridículo, as zombarias, um apelido irônico que a persiga até à morte. Fácil compreender o sofrimento psicológico disso decorrente e sua influência na gênese e na estruturação, em alguns, do complexo de inferioridade. Cabelos vermelhos, u'a marca de nascença visível, malformação de orelha ou do nariz, um sexto dedo na mão, sindactilia, lábio leporino, estatura demasiado baixa ou alta em demasia, corpo disforme, uma fealdade extrema, etc., etc. - e, se quiséssemos, poderíamos estender em muito a lista.

Estas, as três causas principais. Que, muitas vêzes, trabalham isoladas, podendo, entretanto, fazê-lo juntas, conjugando fôrças na formação do complexo de inferioridade.

\section{IV - DINÂMICA DO COMPLEXO DE INFERIORIDADE}

Instalado o referido complexo, fácil compreender o sofrimento que acarrete. Dá-nos disso notícia o poeta Felipe de Oliveira, contando que, u'a manhã, na praia,

"Os corpos úmidos desenrolam

a ronda dos troncos harmoniosos, dos seios em ponta, das espáduas queimadas, das coxas lisas; buscam-se, penetram-se à distância, atropelam-se nas fugas ágeis sem perceber 10 rapaz corcunda, de "maillot" prêto amargo e imóvel, recurvo, arqueado em $G$ maiúsculo que pensa, triste, a olhar, de longe, o atleta de [camisa verde:

- Se o mundo fôsse de corcundas, eu, de certo teria nascido como êle..."

Voltando ao tema, como se defende o indivíduo do seu complexo de inferioridade? Como reage face ao dito complexo? É o que veremos, a seguir. Êsse complexo (complexı sim, porque atua no subconsciente) pode dar azo a diferentes maneiras de conduta, da rebeldia à resignação, da timidez ao despotismo, da fanfarronada ao talento, da maldade à com- 
placência, da cobardia ao heroísmo, da abulia à sublime exaltação da vontade, da neurose ao crime, ao suicídio até.

O mecanismo de defesa, de que se vale o indivíduo para lutar contra sua inferioridade, é sempre o mesmo: a compensação. Não sendo possível suprimir a minusvalia, orienta seus esforços num sentido contrário, visando equilibrá-la.

A compensação seria, portanto, um artifício usado pela natureza para remediar uma insuficiência e restabelecer, na medida do possível, o equilíbrio. Vêmo-lo, no organismo, quando se extirpa órgão de um par e o órgão restante, pela chamada função vicariante, procura suprir a falta do órgão removido; no indivíduo que, tendo um dos membros inferiores mais curto que o outro, acaba por apresentar uma curvatura, compensadora, da coluna, que lhe impede a queda; no coração que, apresentando uma lesão, se hipertrofia para compensar a mesma, etc.

No caso de que nos ocupamos - complexo de inferioridade - o que se observa é, também, uma verdadeira compensação. Ou melhor, duas diferentes formas de compensação: a dos que triunfam da sua insuficiência - a que se denomina compensação triunfadiora, ou heróica - e a dos que não o logram fazer e, neste caso, falamos de uma compensação protetora, ou dissimuladora.

Por uma questão didática, deixaremos a primeira para exame ulterior, fixando-nos, antes, na apreciação da última forma. Vejamos, assim, em primeiro lugar, algo sôbre a compensação dissimuladora ou protetora.

\section{1) - COMPENSAÇÃO PROTETORA, OU DISSIMULA- DORA}

Quando o indivíduo, portador de um complexo de inferioridade, não logra triunfar do mesmo e se compenetra de, efetivamente, "ser inferior aos demais", surge, nêle, o desejo de, já que não pode ser igual aos outros, pelo menos parecer que o é. Dir-se-ia que raciocina assim: "já que sou menos, procurarei parecer que sou mais". Nascerá, nêle, um sentimento de superioridade (êste, note-se, de maneira alguma, é normal), de que se poderá originar um complexo de superioridade (complexo sim, porque passa a atuar no subconsciente), 
complexo de superioridade êste que nada mais é, em derradeira análise, que um processo de que se vale para fugir às dificuldades acarretadas por seu complexo de inferioridade.

Exemplifiquemos: Certos povos que se jactam de pertencer a uma "raça superior"; determinados caçadores e pescadores que relatam maravilhas de inexistentes proezas venatórias e piscatórias; "grandes conquistadores" de mulheres que grassam por aí, contando, de bôca cheia, como são irresistíveis junto às damas, vangloriando-se de incríveis façanhas sexuais; fanfarrão que discorre, cheio de basófia, sôbre o arrojado de sua bravura e que, não raro, carrega um arsenal na cintura, "para mostrar que é macho de verdade!" nada mais fazem que realizar uma compensação protetora, face a uma debilidade própria, secreta, reconhecida e inconfessada. Dessa maneira, tôda a psicologia adleriana se apoia no provérbio popular: "Dize-me do que te gabas, e eu direi o que te falta!"

Lugar à parte merece o estudo da psicologia do "chauffeur", com êsse perigoso instrumento de compensação que é o automóvel: as criaturas menos inteligentes, mais débeis e mais lerdas, podem, sem trabalho, outorgar-se o prestígio do poder e da rapidez, propiciando-se o prazer de ultrapassar a todos os outros... na estrada. Nas ruas então, vale a pena observá-las: bradam, vociferam, chamam a outrém de "palhaço" e "barbeiro", gesticulam, reclamam, buzinando, com insistência, se não lhe dão caminho - querem sempre passar à frente dos demais... Chegam mesmo a atropelar, matar. Indagaram a alguém, "que era uma fração de segundo"; respondeu: "é a fração de tempo que medeia entre o instante em que a luz do sinal de tráfego passa de amarelo a verde, e o toque, irritado e repetido, da buzina do carro que está atrás do nosso". Automóvel de um dêsses tipos humanos que estudamos - desnecessário dizer.

"Pela velocidade", escreveu alguém, "os homens podem igualar-se aos deuses". "A aceleração, as bruscas ascenções de velocidade é que, geralmente, nos agradam" - observa conhecido pilôto; por isso é que muita gente prefere o avião ao automóvel. Nas estradas, são sem conta os apaixonados da velocidade, que se libertam de grande número de complexos: "you drive, as you live" - lição de psicólogos ianques; 
está certo: dirige-se um carro como se vive... Alguns maridos "vingam-se", na direção dos seus carros, da brutalidade que lhes inflingem as mulheres. Observadores da alma humana assinalam, entre motociclistas vítimas de acidentes, elevada proporção de impotentes sexuais; procuram compensar-se com a "potência" da máquina.

A imprensa, o rádio, o cinema e a televisão, colocam, em pé de igualdade, pessoas apagadas, inexpressivas ou feias, com campeões da inteligência, heróis da coragem, rainhas da beleza - das quais, na vida real, estão separadas por verdadeiros abismos. Certos filmes ou certos programas fazem algumas crituras viverem as melhores horas da sua vida; não estará nisso o segrêdo do sucesso de muita rádio-novela, ou de novelas da TV?...

Muitas vêzes, na vida, o indivíduo procura meios em que aparece como desejaria ser: não são raros os tímidos sem remédio, em face da beleza avassaladora da mulher e que, no entanto, escrevem versos de ardente luxúria, ou se derramam através de páginas de amor incandescente. Na realidade, porém...

Dentro da mesma ordem de idéias, recordemos ser proverbial a melancolia dos palhaços, ser clássica a amargura dos humoristas: fazem rir aos outros; êles, porém, são criaturas... tristes.

Não sabemos até onde erramos, vendo atitude vital compensatória a um complexo de inferioridade, na vivência de rebeldia da "juventude transviada", e que com razão maior deveria intitular-se "juventude desajustada". Na realidade, geração nem melhor, nem pior que outras: apenas diferente. Sofredora, insatisfeita, desesperada, moral e psicològicamente desarvorada. Fruto de pais neurosados ou irresponsáveis, integrada, muitas vêzes, por "órfãos de pais vivos", vítima de abandono moral e afetivo (o grosso do exército de "play-boys" é integrado por filhos de gente "bem"), vinda de um passado inquieto, vivendo um presente incerto, voltada para um mundo sem amanhã - compreende-se se procure "afirmar", através de tropelias e arruaças, da indisciplina e da rebelião, do crime mesmo. A testemunhar que é u'a mocidade angustiada, documentêmo-lo nós, psiquiatras, que os vemos, aos mo- 
ços de hoje, em legião, em nossas clínicas, prêsa da neurose e - o que é mais impressionante - da neurose sexual.

Muitas vêzes, malogrado no seu intento de realizar a compensação, o indivíduo refugia-se na ficção, na terra doirada dos "faz de conta", em que se imagina situações em que não seria tão infeliz. E o sonhar acordado, o devaneio, a fuga de si mesmo, o running away, o "escapismo".

Casos há em que as coisas assumem aspecto mais sério, e temos, então, aquilo a que Adler denomina falso estilo de vida. Quando não se refugia na ficção, o indivíduo tomba no vício, ignorando que - em palavras de Modinos - "entra en el templo de la Quimera por la puerta del sueño y sale por la puerta de la agonia": o compositor Stephen Foster, dilacerado por conflitos íntimos, rende-se à bebida; Edgar Allan Poe, humilhado, ferido pela calúnia e pelo abandono, embriaga-se, até acabar caído, na sarjeta. Se não se entrega ao álcool, ou a qualquer outro vício, "para afogar as mágoas", o infeliz se refugia na neurose: "refúgio na enfermidade" (Flücht in die Krankheit), passando a doença a ser o abrigo, a trincheira detrás da qual se esconde para não sair para a luta - e isso explica porque muitos neuróticos dêste tipo difìcilmente se curam: incompreensível que pareça, não desejam, realmente, ser curados, embora procurem médicos e vivam a proclamar seu desejo de ficarem bons. É que a cura, para êles, é "péssimo negócio", pois significará a volta à batalha da vida, a que fogem com tanto mêdo. Ademais, a doença tem duas finalidades: a primeira, atrair simpatia e piedade sôbre o "pobre enfêrmo", a que todos, em casa, mimam, agradam, nada lhe deixando faltas; a segunda, servir de pretexto honroso para não lutar: "como trabalhar, se não posso, se estou doente?". E isso deixa intacto seu self respect (respeito próprio) - diz Ross Jones.

Procuram, muitos, se afirmar, através do crime. Claro que não nos deteremos no assunto. Recordemos, de passagem, que o furto, no menor, é, na quase totalidade dos casos, puramente reativo. Estudam, a propósito, muitos tratadistas o chamado "furto de compensação", ou "furto de consolação", praticado por crianças impelidas por móveis afetivos ou condições sociais desfavoráveis (perda ou ausência de amor, 
abandono moral e afetivo, reação a conflitos familiares, pauperismo, etc.).

Entre os muitos crimes por complexo de inferioridade, registrem-se os referidos por Abrahamsem: um, cometido por indivíduo cego de um ôlho; outro, por ser gago; dois, por serem portadores de pé-torto.

Tivemos oportunidade de dizer que pode haver complexo de inferioridade por excesso de... mimo. Assinalemos, aqui, o problema do filho único (enziges Kind, dos autores alemães; overprotected child, ao dizer dos psicólogos ianques), cercado de excessivo carinho, deslisando, suavemente, por uma infância a que parentes extremosos limam arestas e asperezas - difìilmente suportará os embates que a vida, tantas vêzes madrasta, lhe reservará, cá fora. Se alguns superam o problema, baquearão, outros, às garras da neurose, do vício, da psicose, do suicídio. Quando não, querendo afirmar-se a qualquer preço, enveredarão pela senda do crime.

Exemplo, recente, em França, de Georges Rapin, filho único de engenheiro de grande projeção mundial, sempre ausente do país e do lar, desassistido por mãe fútil sempre às voltas com o "society", perdido pelas demasias de dinheiro de uma avó carinhosa além das medidas - acabaria adotando o nome de guerra de "Monsieur Bill", fazendo-se êle, frustrado, um GRANDE, no sub-mundo de Paris, enveredando, por fim, na senda do crime, matando diversas pessoas. Prêso, confessa tudo. Ao sair do gabinete do juiz de instrução, diz aos fotógrafos da imprensa: "Obrigado, senhores, por serem tantos. Devo ser mesmo alguém. Os senhores têm razão em me quererem fotografar, hoje: é o mais belo dia da minha vida!" Condenado a morrer na guilhotina, comporta-se como o jogador que jogou e perdeu - e sua atitude é, ainda, de desafio à Sociedade. Não será tão serena a de seu pai que, acabrunhado, deixa o tribunal: acompanha-o a multidão, aplaudindo a decisão da Justiça; e condenao, a êle, agora, pela educação que deu - ou melhor, que não deu - ao filho que vai morrer. 
Falámos, até aqui, em crime, por fôrça de um complexo de inferioridade contra uma pessoa, ou contra pessoas. Falemos, agora, naqueles casos em que a ação daninha de um complexado dessa natureza se volta contra uma nação, ou contra nações: Tamerlão (côxo); Ivan o Terrível, Torquemada e Bonaparte (epiléticos); Nero, Calígula e Tibério (psicopatas), o kaiser Guilherme II (braço esquerdo paralisado e mais curto que o direito) - fizeram pagar caro aos do seu tempo. Há um traço comum entre o conquistador, que tala povos e depreda nações, e Lampeão e Antônio Silvino, que devastam o sertão. Mussolini - filho de ferreiro de aldeia que jurou "fazer da sua vida uma obra-prima", fêz o que fêz e acabou como se sabe.

Falta-nos perspectiva histórica para julgar ao Duce e ao Führer. Os eventos estão ainda perto de nós, para uma perfeita apreciação. Escreve-se tanta coisa sôbre Hitler! Diz-se, por exemplo, que o "braço erguido", imposto a milhões, a título de saudação, serviria de "gesto compensador" à falta de ereção - impotente sexual que era; dêle ainda, conta-se que a circunstância de ter tido recusado um quadro, com que pretendeu concorrer à Galeria de Munich, em 1919, por uma comissão de cinco membros - três dos quais judeus - fê-lo voltar a pintar paredes (seu ofício), mas fêz dêle, também, o feroz anti-semita que conhecemos.

Outra reação compensatória é o suicídio. Particularmente, o chamado suicídio-vingança; mais freqüente na adolescência, é também observável em adultos. Em casos assim, o portador de complexo de inferioridade como que procura, com sua morte, "vingar-se" do ambiente, de, com sua morte, fazer sofrer a determinada pessoa, ou pessoas, "que não o souberam compreender, em vida".

Vimos, até aqui, falando da compensação protetora, ou dissimuladora. Vejamos, a seguir, a

\section{2) - COMPENSAÇÃO TRIUNFADORA, OU HERÓICA}

Temos, agora, o indivíduo portador de um complexo de inferioridade, que recebe sua inferioridade, não como um capitis diminutio, mas como um desafio a estimular seu instinto combativo. É como se raciocinasse: "Acreditas que me vencerás, mas sou eu, sim, quem te derrotará!". Não só com- 
pensa; vai além: supercompensa sua inferioridade, desenvolvendo, na luta por essa vitória, ignorados tesouros de energia e perseverança. Não só iguala aos demais, na sua mediania: ultrapassa-os, muitas vêzes deixando rastro luminoso na História.

Conhecem-se exemplos, exemplos e exemplos. Citemos alguns dêles, dando, assim, início ao desfile de

\section{COMPLEXADOS QUE SE AFIRMARAM NA VIDA}

Heine, Keats, Stevenson, Pope, Parkman, Kant, Chopin, Wagner, Massenet, Dostoievski, Bacon, Scarron, Lamartine, Alarcon e tantos outros, tiveram vida e caráter modelados por suas insuficiências. Insiste Adler em que $70 \%$ dos pintores famosos teriam sofrido de algum defeito visual: a ambição de vencer sua debilidade, foi o primum movens de seu êxito.

Até onde teria influído a epilepsia nas vidas de Maomé, Júlio César, Bonaparte, Pedro o Grande, Flaubert, Dostoievski, Newton, Pascal, Machado de Assis, Van Gogh e tantos outros? Há quem acrescente a esta lista de portadores de "sacer morbus" ("mal sagrado", dos antigos) os nomes de Hércules, Luiz XIII, a rainha Vitória, Berlioz, Paganini, Newton e outros. Psicopatas como Rousseau, Pestalozzi e Roberto Mayer, influiram no curso de nossa civilização.

Quantos neuróticos procuram - e conseguem - sublimar sua neurose, na Arte, na prosa e na poesia: "Se a tua dor te atormenta, faze dela um poema!" - ensina poeta das Américas. Na obra poética de Esquilo, Shakespeare, Augusto dos Anjos, Carlos Drummond de Andrade, Rainer Maria Rilke, Raul de Leoni e tantos outros, sente-se, nítida, a "presença" da melancolia; daí, haver intelectual francês escrito: "... et j'en sais d'Immortels qui sont de purs sanglots": suas obras são um soluço só...

Goya, pintor, começou a sofrer do ouvido, na mocidade; mais tarde, ficou completamente surdo, o que não impediu viesse a realizar quadros notáveis, nem, muito menos, viesse a ser amado pela bela Duquesa de Alba (a magnífica "Maja desnuda", que retratou) - tinha êle 55 e ela 33 anos - amor êste que realizou o milagre de fazer seu espírito desabrochar, florescer. 
Certa feita, o compositor Handel se viu numa situação desesperadora, com o lado direito paralisado, sem dinheiro, ameaçado de prisão pelos credores; o sofrimento incitou-o ao maior esfôrço da sua vida: trabalhando febrilmente, sem parar, compôs o "Messias" com seu monumental côro "Aleluia", em apenas 24 dias!

A primeira ópera de Wagner - "Rienzi" - foi estrepitosamente vaiada, quando de sua representação. Outro teria desistido; não Wagner que, dêsse insucesso, partiu para o êxito.

A maioria dos grandes homens teve origem humilde - 0 que se pode verificar através da biografia de Cícero, César, Galileu, Dante, Leonardo da Vinci, Newton, Laplace, Goethe, Voltaire, Rousseau, Heine, Spinoza, Descartes, Hegel, Lincoln e outros.

Machado de Assis, mulato, nascido no morro, epilético, ascende de tipógrafo humilde às culminâncias da literatura. Tamerlão, Genserico, Shakespeare, Byron, Walter Scott e Talleyrand, foram coxos e, embora coxeando, souberam andar mais depressa que seus contemporâneos.

Edson, surdo, realiza, entre outras invenções, a gravação do... som. Beethoven, murado vivo na sua surdez, sabe "ouvir" belas melodias que nos legou. Só depois de perdida a visão, é que Milton consegue "ver" as belezas do "Paraíso Perdido". Hellen Keller, aos 19 meses de idade, fica cega e surda, em conseqüência a grave enfermidade; olvida as palavras aprendidas, exceto uma - water: água; pois bem, reaprende a falar, aprende a ler e escrever, gradua-se numa universidade, escreve livros, faz conferências e torna-se digna que se a intitule "milagre humano".

Demóstenes, adolescente fraco e tímido, é também gago; luta contra sua gagueira e acaba o maior orador de sua época; inspirará, com seu exemplo, mais tarde, a Charles Lamb, Winston Churchill e outros, que farão da sua espasmofemia clônica, a alavanca com que vencerão na vida.

A paralisia infantil não logrou derrotar a Roosevelt, Nana Gollner, Ted Shawn e Glenn Gunninghan, que chegaram a grande estadista, o primeiro, bailarinos famosos a segunda e o terceiro, campeão olímpico de corridas o último. A mes- 
ma doença acometeu a outros dois e a Medicina, "infalível", prognosticou que "jamais voltariam a andar"; não só andaram, como aprenderam a correr, e a correr bem, tanto assim que se sagraram campeões nas últimas Olimpíadas, em Roma, sendo que um dêles - mais precisamente, a americana Wilma Rudolph - correu com velocidade tal, que a cognominaram "gazela negra".

$\mathrm{E}$ há os feios, que fazem, da sua feiura, a "cicatriz dolorosa" que lhes envenena a vida. Sentem-se inferiores, sentem-se infelizes por isso. As mulheres, em especial. Nada mais relativo; diz um ditado popular que "mulher, fita e chita, não há feia nem bonita". Há feias, fìsicamente falando, senhoras de inteligência tal, que, ao cabo de meia hora de palestra, se tornam as mais lindas das criaturas; há feias como aquela Jane Champion, da formosa novela "O Rosário", de Florence Barclay - às quais o amor pode tornar belíssimas. E há feias capazes de provocar paixões abrasadoras; quem o afirma é o poeta português Júlio Dantas - e foram sem conta as mulheres que amou - e falava, sem dúvida, em causa própria, confessando experiência a respeito:

"Hoje estou convencido, ó minha gloriosa:

A paixão sem beleza é a mais perigosa, O amor por uma feia é o maior que existe!"

E há as menos belas, como, por exemplo, Katherine Hepburn e Joan Crawford, "as meninas mais feias do seu tempo", que se souberam tornar formosas, através da Arte. De artistas cinematográficos, como Jimmy Durante, Joe Brown, Lon Chaney, Edward Robinson, Peter Lorre e outros, costuma-se dizer que "a feiura foi o seu capital". Voltaire e Mirabeau teriam encontrado, na sua fealdade, o motor para o êxito. Perguntaram a um certo político nacional, notável por sua carantonha, "por que não usava outra cara"; ao que - com raro senso de humour, respondeu: "Uso a cara que Deus me deu; e vocês acham que se eu tivesse outra, andaria por aí, com esta?" Assim é que faz!

Pasteur, ainda moço, ferido por um ictus, fica hemiplégico; julga-se liquidado, inválido e estuda, a sério, a possibilidade de matar-se; não o faz, luta contra a enfermidade, vem a transformar-se em grande benfeitor da Humanidade. Igual, 
a história de Annie Besant, a conhecida chefe da seita teosófica inglêsa; é ela mesma quem o conta:

"Depois de violenta altercação com meu espôso, senti-me ultrajada, desesperada, sem achar porta de escape da vida, perdida a confiança em Deus... Sem porta de escape? - como um relâmpago, atravessou-me a mente a idéia: eis aqui uma. $E$, diante de mim, vi aberta, como sonho de paz e libertação, a porta do silêncio e da segurança: a porta da tumba! Estava de pé, junto à janela da sala, fixas as pupilas desesperadas no céu vespertino. Com a idéia da morte, pensei que tinha meios de procurá-la para mim: o clorofórmio, que aliviara os sofrimentos de minha filha, estava no andar de cima. Galguei as escadas, apanhei a garrafa, desci, quedei-me, de pé, junto à janela, contemplando a tarde que morria, contente pelo término da luta e pela aproximação da paz. Destampei a garrafa, ia levá-la aos lábios, quando ouvi palavras doces, claramente pronunciadas: “ $O$ ' covarde, covarde que aspiraste ao martírio, e não podes suportar uns anos de dor!" Invadiu-me uma onda de vergonha, arremessei longe o frasco e, por um momento, me senti fortalecida para a luta. Só mais uma vez, nas minhas lutas posteriores, pensei no suicídio; apartei de mim a idéia, como indigna de umà alma forte!"

Porque muito lhe estava reservado ainda, a realizar como realizou - numa vida digna de ser vivida.

Paderewski - grande pianista e homem-de-Estado polonês - tinha as mãos tão fracas que lhe foi aconselhado desistir, pois "jamais viria a tocar coisa que valesse a pena, ao piano".

Camões, cego de um ôlho, legou-nos "Os Lusíadas"; viria consolar, séculos mais tarde, ao nosso poeta Vicente de Carvalho, que, ao lhe cortarem o braço, fillosofou: "Não faz mal; Camões era "amputado" de um ôlho, eu fiquei "cego" de um braço".

O fabulista Esopo e o poeta Leopardi eram corcundas. 
Bilac, vesgo. Walt Disney, paralítico de um braço. O compositor patrício Nazaré, surdo.

Cervantes, maneta depois da batalha de Lepanto, vê truncada sua carreira militar; graças a "Don Quixote", entra para a galeria dos inválidos geniais, que iluminaram o mundo.

A Einstein, ao Padre Vieira, a Edson, aos famosos médicos Billroth, Koch, Karl Schleich, Virchow e a Rocha Pombo - retardados escolares - foi dito que melhor fariam desistindo do estudo...

Com vistas a pais e educadores, recordemos que foram dados, como "futuros imbecís", Temístocles, Cimon, Luis Caracci, Dominiquino, George Sand, Balzac e outros, cujo talento ofuscaria, mais tarde, seus contemporâneos e mesmo gerações porvindoiras. Entre êsses "retardados", há citar, em destaque, a Santo Tomás de Aquino: taciturno, caladão, os colegas de escola, na Itália, o chamavam de "il bue muto" (o boi mudo); e que mudo! Quando começou a falar, foi a Summa, foi o Tomismo que nos legou.

Agustin Lara e Noel Rosa, feios e disformes, tornam-se formosos quando lhes ouvimos a música.

Literatos como Ribeiro Couto, mulato, Álvaro Lopes, mulato e surdo, Sommerset Maughan, gago, os mestiços Padre João Maurício, músico, Rebouças e Patrocínio são outros exemplos, a que poderemos acrescentar o pintor Toulouse-Lautrec, paralítico..., e o nosso Aleijadinho, que sublimou tôdas as suas dores nas belas obras de arte que conhecemos.

Charles Chaplin, filho do bas fond londrino, alça-se à genialidade. Cruz e Souza, prêto, brilha na poesia, em que se nos depara, a cada passo, a "branquidade" almejada. Descartes era, ao nascer, débil e enfermiço; disseram que não se criaria; foi, mais tarde, o grande Descartes.

Voltaire, Renoir, Darwin, Newton e Bonaparte, prematuros, eram tão franzinos que lhes foi vaticinada a morte, ao virem ao mundo; não concordaram com os médicos, pois tinham muito a realizar.

O mesmo Bonaparte, cadete baixinho, miúdo, desconfiado, humilhado pelos colegas, em virtude de sua baixa estatura, por sua pele moreno-escura, por seu sotaque corso - acre- 
dita-se derrotado pela vida; tenta matar-se, na Escola Militar de Brienne; não morre; luta, super-compensa-se, tudo fazendo para se tornar - como se tornou - Napoleão, O GRANDE, na História. Pela mesma razão, Alexandre; Nelson D'Annunzio, teriam sido impelidos a procurar a glória.

Por uma surdez, na infância, Johnnie Ray e Leo Calabrese vêm a tornar-se grandes cantores.

Nietzsche, adolescente tímido, míope, leva vida solitária, monástica quase; é o mesmo que, mais tarde, proclama: "O que não me mata, torna-me mais forte!", princípio que iria nortear sua filosofia moral da "vontade para o poder" e o mito do Super-homem.

"Sem a moléstia que me prendeu ao leito, durante tantos anos, eu jamais teria descoberto as leis da seleção natural" confessa Darwin. “Qui n'a jamais été malade ne s'et jamais connu tout entier" (Quem nunca esteve doente, jamais se conheceu completamente a si mesmo) - assinala Romain Rolland. A enfermidade, deixando-nos a sós conosco mesmos, propicia horas "de intimidade" com a própria pessoa, da qual a vida agitada de hoje nos aparta, amiúde. Referindo-se à doença de Wilson (defeito no calcanhar), disse alguém que doenças assim foram antes um bem que um mal, por isso que, mantendo-os presos ao leito, obrigaram seus portadores "às orgias silenciosas da meditação". Aí, talvez, a razão de o cientista suíço François Huber, cego de nascença, haver-se tornado mundialmente famoso por seus estudos sôbre a vida e os hábitos das abelhas. Não fôra a noite da cegueira, e não teríamos a "Ilíada" e a "Odisséia" de Homero; o "Paraíso Perdido", de Milton e as obras de Castilho.

\section{V - LIÇÃO A CONSERVAR}

Chega de exemplos, que a lista já se está tornando cansativa. Poderíamos citar centenas, milhares dêles. Não o faremos, para não nos alongarmos em demasia.

Para que insistir em alinhar nomes, nomes e nomes? Finalizemos, repetindo lição sobremodo conhecida: um complexo de inferioridade pode ser um mal - algumas vêzes é. Pode ser, também, uma bênção - e quantas vêzes é!

Bênção, por que? Porque, devidamente compensado - 
usada, aqui, a palavra compensação no sentido triunfador ou heróico, que é construtivo - poderá levar seu portador ao êxito. Pode mesmo ser, por si só, a única condição dêsse êxito.

Funcionando como acicate, a esporear, estimulando-o a todos os instantes, faz com que o indivíduo caminhe para a frente, sempre para a frente, cada vez mais para a frente para alcançar e, não raro, ultrapassar os demais.

Com a palavra Churchill, a que já nos referimos: "Todos os grandes homens que conheço, são produto de infâncias infelizes" - e com razão o diz, porque gago, como Demóstenes, como Demóstenes venceu sua gagueira e tornou-se grande orador.

"Não é a ferramenta que a pessoa possui e sim a maneira de a usar, que determina sua posição na Sociedade" - lembra, com sabedoria, H.B. Walters. Não importa o que se trás, na vida; importa, sim, o que se fará com o que se traz.

"As enfermidades podem quebrantar os atos do corpo, mas não os da vontade" - a lição é de Epitecto, filósofo-escravo grego, que diz mais: "Sendo eu um côxo, isso poderá ser obstáculo para meu pé, nunca para mim mesmo; pensa dêste modo em todos os acidentes que te ocorram, e verás que para tudo podem ser obstáculo, menos para ti!"

Conta-se que, certa feita, alguém encontrou dois operários, a trabalhar, cada qual, seu bloco de granito. Tarde de verão; calor; sol a pino. Indagou de um dêles o que fazia:

- Ora, que pergunta! Dando um "duro desgraçado", neste trabalho horrível, morrendo de calor e sêde nesta solina infernal!"

Voltou-se para o outro:

- E você, amigo, que faz?

- Eu? Então não vê?! Pois estou ajudando a construir uma catedral! 